Scholarship Repository

University of Minnesota Law School

Articles

Faculty Scholarship

1999

\title{
American Prisons at the Beginning of the Twenty-First Century
}

Michael Tonry

University of Minnesota Law School, tonry001@umn.edu

Joan Petersilia

Follow this and additional works at: https://scholarship.law.umn.edu/faculty_articles

Part of the Law Commons

\section{Recommended Citation}

Michael Tonry and Joan Petersilia, American Prisons at the Beginning of the Twenty-First Century, 26

CRIME \& JUST. 1 (1999), available at https://scholarship.law.umn.edu/faculty_articles/490.

This Article is brought to you for free and open access by the University of Minnesota Law School. It has been accepted for inclusion in the Faculty Scholarship collection by an authorized administrator of the Scholarship Repository. For more information, please contact lenzx009@umn.edu. 


\section{American Prisons at the Beginning of the Twenty- First Century}

The effects of America's contemporary experiment with mass imprisonment will be clearer twenty-five years from now. The answers to some important questions, however, including whether vastly increased use of imprisonment has substantially enhanced public safety, will never be clear. The problem is one of covariance, that changes in things we measure that appear to be related to each other may not be related at all but instead may both be causally related to something else. In some northerly regions, for example, robins return from their winter vacations in February, their eggs hatch in April, and apple blossoms appear in May. It happens every year. Robins' vacation or reproductive predilections have, however, nothing to do with apple trees. Both are responding to changes in ambient temperature and climatic conditions. Apparent relations between crime and punishment may be similarly misleading.

Rising crime rates may affect imprisonment rates, or rising imprisonment may affect crime rates, or both may be affected by something else. If, for example, a broad-based, long-term change in social norms toward greater personal responsibility and respect for the interests of others were under way, it would be reasonable to predict that crime rates would fall (fewer people would choose to behave irresponsibly) and imprisonment rates would rise (many people would be more intolerant of wrongdoers and thus more inclined to punish them harshly).

Michael Tonry is director, Institute of Criminology, Cambridge University, and Sonosky Professor of Law and Public Policy, University of Minnesota Law School. Joan Petersilia is professor of criminology, law, and society, School of Social Ecology, University of California, Irvine.

(c) 1999 by The University of Chicago. All rights reserved.

0192-3234/1999/0026-0010\$02.00 
Observers might well infer that increased imprisonment reduced crime rates. They might be right, or wrong, or partly right and partly wrong. The absence of a causal relationship between the activities of robins and the blossoming of trees is well understood; we understand and know how to measure changes in temperature and climate, and to predict their effects on robins and trees. Unfortunately, we do not understand what makes crime and punishment patterns change.

The world keeps changing, and it is often impossible to know why things happen when they do. The rapid increase during the 1990s in the numbers of people confined in prisons and jails coincided with falling crime rates. A cross section of lay people, public officials, and scholars believes that the deterrent and incapacitative effects of increased imprisonment caused crime rates to fall. Other cross sections of those groups believe that changes in policing strategies (e.g., community and problem-solving policing) and tactics (e.g., zero-tolerance policing) deserve substantial credit. Still others credit the robust and record-length economic expansion and related low unemployment rates of the $1990 \mathrm{~s}$, or they credit deeper, more fundamental, but more elusive social-structural changes that appear to be leading to falling crime rates throughout the Western world irrespective of the content or severity of countries' penal policies (Mayhew and van Dijk 1997). There are plausible cases, and plausible refutations, to be made for each of these claims. Each, no doubt, has some merit, but we will never know how to apportion credit among them or, more important, which deserve primary credit.

Likewise, whatever the future holds, we are unlikely in 2025 to know how the coming quarter century's imprisonment policies, whatever they prove to be, have affected crime rates. Imprisonment rates and numbers may continue to rise, or stabilize, or decline, or fluctuate. The current economic expansion will end, as all economic expansions do, and economic cycles will continue, as they always have. American social welfare policies will continue to be less generous than those of other Western countries, or they will move more toward the mainstream, or they will move in each direction at different times. Criminal justice policies, .practices, and laws will become harsher or less harsh or will alternate. The movement toward privatization of prisons will continue, or slow, or contract, and private prison operators and employees will or will not become effective lobbyists for creation or maintenance of high-prison-use policies. And if deeper social-structural changes in American (or Western) society are primary determinants of 
crime-rate trends in recent years, those changes may continue or may alter direction. And something will happen to crime rates, and thoughtful people will disagree deeply about what caused what.

Nor, looking backward, is the relation between penal policy and crime rates and patterns any clearer. There is wide agreement among historians, for example, that crime rates, especially violent crime rates, fell steadily in many Western countries from early in the nineteenth century until the middle of the twentieth century, after which they began steep rises. Historians refer to this pattern as a "U-curve" or, sometimes, a (backwards) "J-curve," to make the point that twentiethcentury violence rates never regained their early nineteenth-century heights. There is likewise wide agreement that crime posed vastly greater dangers to residents of early nineteenth-century cities than to residents of twentieth-century cities. But there the agreement ends.

There is no agreement on why crime rates fell for more than a century. Some argue that the increased bureaucratization of modernizing, industrializing, and centralizing countries changed socialization patterns and in effect trained people to conformity (Lane 1980, 1989, 1992; Gurr 1989a, 1989b). Some claim that religious revivalism and a moral reawakening in the nineteenth century affected basic beliefs and values and with them the socialization people received in families, schools, churches, and communities (Wilson and Hernstein 1985). Some claim that the decline was the result of a general, much longerterm "civilizing process" that has affected at least all Western societies, and to which the increased crime rates of the 1960s-1980s are simply a short-term anomaly (Elias 1978, 1982). Most strikingly, virtually no one attributes the long-term decline to changes in sentencing policies or to criminal justice innovations, even though all of the institutions of modern American criminal justice systems (professional police, imprisonment as the modal punishment, probation, parole, the reformatory, indeterminate sentencing, the juvenile court) were created between 1830 and 1900 and ubiquitous by 1930 (Rothman 1980; Friedman 1993; Walker 1998). In relation to criminal justice innovation in the nineteenth century, the absence of claims about effects on crime rates is the dog that didn't bark, and no one noticed.

All this is a pity, because prison and jail populations of the past quarter century result from conscious policy decisions by federal and state lawmakers, premised on propositions about the crime-preventive effects of harsher and more certain punishments, and the validity of those propositions is the fundamental question to be answered about 
the wisdom of modern penal policies. Wisdom incorporates not only knowledge and experience, however, but also values. In the end, penal policies derive from normative premises and valucs, and penal policies might better be served if they were openly and honestly debated in those terms.

Even if the answers to first-order questions about aggregate behavioral effects of penal policies on crime, including imprisonment policies, are probably unknowable, much more is knowable about secondorder questions concerning effects of imprisonment in general, and of various prison regimes and programs in specific, on prison staff, prisoners, their families, their communities, and public spending. Surprisingly little is known, but much is knowable.

Imprisonment policies beginning in the 1970s leapt far ahead of knowledge about prisons and prisoners. Until then, the largest bodies of systematic empirical research concerning prisons consisted of a sizable but highly variable body of studies on the effectiveness of correctional treatment programs (Lipton, Martinson, and Wilks 1975), a smaller body of recidivism studies (e.g., Ohlin 1951; Glaser 1964), and a sociological literature on inmate socialization and subcultures (e.g., Clemmer 1940; Sykes 1958; Sykes and Messinger 1960; Jacobs 1977). Since then, as a result of the proliferation of criminal justice and criminology programs created in the wake of the Law Enforcement Assistance Administration, the number of researchers interested in prisons increased greatly, but the absence of sustained commitment of research funding from government agencies and foundations frustrated efforts to build a vital prisons research community. Foundations for many years exhibited little interest in research on the adult criminal justice system, including prisons and prisoners, and until recently federal research-funding agencies focused nearly all their attention on other subjects.

Nonetheless, as the essays in this volume attest, important work has been done on many prison and prison-related issues. On some topics-for example, the effectiveness of correctional treatment programs (in Canada) and prison regimes (in England)-much of the most important recent work has been done outside the United States. The essays in this volume summarize what is known about a range of important topics, and with what degree of confidence, and what should be learned next. The essays speak for themselves, so we do no more in this introduction than describe a number of issue clusters on which research sheds some light and on which more sustained and strategic re- 
search could shed much more. Prudent policy makers and practitioners presumably want to make their decisions on the basis of evidence, and there are many areas where better evidence could aid in development of better policies.

\section{Collateral Effects of Imprisonment}

People are placed in prisons and jails partly because of moral ideas about desert: people who do certain things, it is widely believed, deserve to be punished. However, utilitarian ideas about public safety provide at least as strong reasons for imprisonment: putting people in prison enhances public safety, it is widely believed, by incapacitating them, by rehabilitating them, by deterring them and others, and by reinforcing basic social norms about right and wrong. Put differently, when desert ideas are set aside, people sent to prison are being used as means to achievement of public ends. For both moral reasons (can using people in particular ways be morally justified?) and practical reasons (how much does using people in this way cost, does it do more good than harm, are there unintended side-effects?), we should want systematically to understand the effects of imprisonment practices and policies. Earlier we mentioned crime control effects of imprisonment. Here the subject is the collateral effects.

The literature on collateral effects is fugitive and fragmentary. At least six kinds of collateral effects can be identified. First, what are the effects of imprisonment on prisoners' later lives? Sizable economic and smaller ethnographic literatures (Fagan and Freeman 1999) convincingly show that imprisonment reduces ex-offenders' subsequent incomes and employment. A policy literature shows that various state and federal laws deny ex-offenders the right to vote or hold office in some places, the opportunity to engage in certain occupations in some places, and the right to receive various public benefits and services in some places (Fellner and Mauer 1998; Petersilia, in this volume). Various literatures show that imprisonment often leads to breakup of families and social relationships and to lessening of parental involvement with their children (Hagan and Dinovitzer, in this volume).

Second, what are the effects of imprisonment on prisoners' later physical and mental health well-being? A psychological literature on coping and adaptation in prison concludes, probably contrary to many lay people's intuitions, that even long-term imprisonment appears to have few lasting mental health effects (e.g., Adams 1992), though some researchers doubt this (Liebling, in this volume). It would be surprising 
if established adverse effects on income, employment, and family functioning were unrelated to former prisoners' mental and physical health. However, a serious, long-term, multiple-measure, longitudinal study of ex-offenders' lives is needed to answer such questions, and none has ever been done.

Third, what are the effects of imprisonment on offenders' spouses or partners and their children? On this subject, the literature is especially thin and fragmented, as Hagan and Dinovitzer (in this volume) show, and the most pressing task is to pull together existing knowledge in order to formulate plausible hypotheses and develop systematic research agendas. Hypotheses would presumably at least address the effects of imprisonment on the financial and social stability of prisoners' families while they were in prison and afterward, on the maintenance of prisoners' relationships with families, and on the short- and longterm well-being and social functioning of prisoners' children. These would, of course, not be simple hypotheses. No doubt sometimes families and partners benefit from the removal of abusive, disordered, or dysfunctional parents and spouses. However, given the strong negative effects on children's well-being of being raised in disadvantaged, single-parent households (Loeber and Stouthamer-Loeber 1986), the effects of imprisonment on spouses and children often are likely to be negative.

Fourth, what are the effects of imprisonment on prisoners' later crime involvement? The negative effects on ex-prisoners' incomes, employment prospects, and family involvement are predictive, according to findings from criminal careers research (Blumstein et al. 1986), of increased offending probabilities. In addition, for centuries, at least since the time of John Howard, the great eighteenth-century English prison reformer, the proposition has been put forward that prisons are "schools for crime," that younger and less experienced prisoners are socialized into antisocial and oppositional attitudes and as a result exit the prison more likely to commit crimes than when they entered. No informed person doubts that this sometimes happens and at least partly offsets any crime-reductive effects of imprisonment (Hawkins 1976). Many European scholars accept it as proven that prison is criminogenic and that prison terms should for crime-prevention reasons be avoided whenever possible (Albrecht 2000). American research on the effects of penalties typically focuses on crime reduction and only sometimes even treats crime-enhancing effects as an offset. If the criminogenic effects of imprisonment are large, contemporary 
research may be overlooking an important part of the crime and punishment puzzle.

Fifth, what are the collateral effects of imprisonment on the larger community? Hagan and Dinovitzer (in this issue) offer plausible hypotheses about effects of recent prison expansion on deployment of public resources (from higher education, particularly, but also other public programs and services, to prisons), on economic development (from inner cities to the usually rural communities where prisons are built), and on community cohesion (in many disadvantaged minority communities, large fractions of the young men are or have been in prison and are thereby disabled from working, parenting, marrying, or otherwise being contributing members of the community). Others have pointed out that imprisonment has become so common an experience in some communities that it may no longer carry meaningful or any stigma and thereby may lose whatever deterrent effects it would otherwise have (Nagin 1998b) or even cause prison styles and values to be exported to the outside community (Anderson 1998; Fagan and Wilkinson 1998).

Sixth, what are the immediate effects on prisoners while being confined in prison? This is the one collateral-effects subject on which there are sizable literatures: on coping and adapting generally, measured in terms of prisoners' physical and mental health (Adams 1992) and in relation to housing arrangements (Gaes 1985), and specifically on prison suicide (Liebling, in this volume).

\section{Crime Control Effects of Imprisonment}

The preceding discussion of research on collateral effects of imprisonment suggests that policy makers have been flying blind, making decisions costing billions of dollars and affecting millions of lives without adequate knowledge of the nature and costs of unintended side effects. A response might be that the primary goal has been to enhance public safety and, possibly regrettably but understandably, the single-minded concern has been the reduction of crime through the deterrent, incapacitative, and rehabilitative effects of increased imprisonment. The relevant literatures, however, are inconclusive, small, for the most part old, and do not provide strong support for contemporary American punishment policies. Literatures addressing four questions appear particularly relevant.

First, has increased use of imprisonment reduced crime rates through deterrence and incapacitation? Presumably most people would 
conclude a priori that a quarter century's quintupling of the prison and jail population must have reduced crime rates. There has, however, been relatively little research in recent years on deterrence and incapacitation effects, and most authoritative reviews of both subjects conclude that, while such effects exist, they are probably modest (Cook 1980; Nagin 1998a, 1998b). So also concluded the most famous examination of the subject, the 1978 report of the National Academy of Sciences Panel on Research on Deterrent and Incapacitative Effects (Blumstein, Cohen, and Nagin 1978). Similar conclusions were reached in successive decades by National Academy of Sciences Panels on Criminal Careers (Blumstein et al. 1986) and Understanding and Control of Violence (Reiss and Roth 1993) and by an exhaustive recent survey of research on deterrence effects commissioned by the Home Office of England and Wales (von Hirsch et al. 1998).

Second, can prisons deliver treatment programs that will enhance public safety by reducing prisoners' later recidivism? The pessimism associated with the "nothing works" findings wrongly attributed to Martinson's famous 1974 article (Martinson 1974; Lipton, Martinson, and Wilks 1975) appears to have passed, and there are grounds for cautious optimism about the positive effects, under some conditions, of some cognitive-skills, drug-treatment, vocational training, educational, and other programs in adult prisons (Gaes et al., in this volume). The conditions, however, are stringent: most notably, program eligibility must be carefully matched to prisoners' needs and risks, programs must be well implemented and adequately funded, and compatible aftercare programs in the community must sustain treatment efforts. The grounds for optimism concerning programs for young offenders and in the community are somewhat stronger (Loeber and Farrington 1998).

Third, in the aggregate, without distinguishing among deterrent, incapacitative, and rehabilitative effects, does increased use of imprisonment reduce crime rates, in general, and have the increases of recent years, in particular, done so? The prevalent answer appears to be yes (Spelman 2000), but the literature, much of it by economists, is highly technical and inaccessible to nonspecialists, mostly dates from the 1970 s, and suggests that effects are much more modest than is widely understood.

Fourth, in cost-benefit terms, is increased imprisonment worth it? This is the smallest and most primitive of the prison crime-prevention effects literatures, and as yet provides few policy-relevant findings. Ex- 
cept for a small literature that tries to compare alternative crime-prevention programs in cost-benefit terms (e.g., Greenwood et al. 1996), the work to date is useful mostly for methodological reasons, by showing how not to pursue such inquiries. For example, the most widely publicized recent work greatly exaggerates the costs of crime by means of inflated imputed costs of victim "pain and suffering" and takes no account whatever of suffering by offenders or pains of imprisonment borne by their partners, children, or communities (Miller, Cohen, and Wiersema 1996). It may be, as Zimring and Hawkins (1991) have argued, that gross cost-benefit assessments of the effects of imprisonment require weighing of inherently incommensurable values and have reached a dead end. Recent efforts to compare the cost and benefits of alternative crime prevention policies may offer more promise (Welsh and Farrington 2000).

\section{Prisoners and Prison Staff}

Thirty years ago, the largest and best-known body of scholarship concerning prisons was the sociological literature on prison subcultures and the socialization of inmates into prison life. That is no longer true, as much because of the waning of that literature as because of the growth of others. Prisons have changed a great deal in the past thirty years, inmate and staff subcultures and interactions between them have changed, and the learning of earlier times may or may not still be valid but at least needs augmentation. Compared with earlier times, many prisons are much larger, inmate populations and staffs are more disproportionately black and Hispanic, many more line and management staff are women, gangs are larger and their influence more pervasive, more prison staff are unionized, a large and growing fraction of prisons is under private management, and the possibility of judicial oversight and intrusion is greater. The sentencing policy changes of the past quarter century and especially the last few years have produced larger fractions of prisoners serving very long sentences, and with them have come increased demands for medical care and other services for the aging and elderly.

The direct causes of the last quarter century's increase in imprisonment are becoming clearer. Changes in sentencing and parole policies and practices, not changes in crime rates and patterns, are the principal cause of the vastly increased numbers of people in prison and of substantially increased percentages of members of minority groups among prisoners. (What is much less clear is why policies and practices 
changed as they did.) Blumstein and Beck (in this volume) show that, over the past two decades, drug policies premised on incarceration of drug dealers and increased probabilities of imprisonment of those charged with crimes have been the major contributors to prison population growth. More recently, increased sentence lengths have become a major contributor. Changes in parole policies have also increased prison populations through the abolition of parole in some jurisdictions, tighter release standards that have the effect of lengthening time served, reduced tolerance of parole condition violations, and greatly increased rates of revocation and readmission to prison (Petersilia, in this volume).

Behavioral, cultural, and social changes in the larger society inevitably impinge on life inside prisons. AIDS and HIV, for example, are more prevalent inside the prisons than out. The proportions of mentally ill and defective prisoners, never small, have been augmented as a result of the 1960s and 1970s movement to deinstitutionalize many mentally ill people (Petersilia 1997a, 1997b). The civil rights and women's movements have importantly affected prisons, as has the political conservatism of recent years. Programs premised on restorative justice ideas are beginning to appear inside prison walls (Pranis 1996).

The mission for scholars of prison life is to reinvigorate that once robust subject by examining new subjects, reexamining old ones, and incorporating new ideas and theoretical perspectives. Recent work in England (Sparks, Bottoms, and Hay 1996), for example, has studied the effects of different management regimes from, among others, the procedural justice perspective that people who believe themselves to have been treated fairly and their interests to have been fairly considered are more likely to perceive the involved institutions and processes as legitimate (Tyler 1990; Braithwaite 1999).

Studies of women prisoners and life inside women's prisons continue to be conspicuously absent, including in this book. There is a small quality literature (e.g., Zedner 1995), but the recent paucity of research on life inside prisons generally has had an even more impoverishing effect on traditionally understudied subjects. Although the proportion of women to men in state and federal prisons remains small (onefifteenth as large on June 30, 1998; Bureau of Justice Statistics 1999), the number of women prisoners has for nearly thirty years been growing faster than the number of men prisoners, and the absolute number $(82,716$ on June 30,1998$)$ is larger than the entire prison populations of France, Germany, or England. 


\section{Prison Management}

Prison managers, like any other managers, need systematic knowledge if they are effectively, ethically, and sensitively to do their jobs. In an important sense, the sociological and other literatures on life inside prisons mentioned in Section III, and the psychological and other literatures on how people adapt to the experience of being prisoners mentioned in Section I, are both management literatures. The English work on legitimacy and order maintenance in prison (Bottoms, in this volume), which studies prisoners, prison staff, and their interactions, all in the interest of understanding how order can be maintained in prisons, for example, is centrally concerned with management.

In practice, however, writing on management tends to come from professional managers and management consultants rather than from social and behavioral science researchers. Riveland (in this volume) provides an account of the major challenges that prison managers have faced during the past twenty-five years and how they have changed over time. A volume such as this one could have addressed any number of important challenges that contemporary prison managers face in addition to those already mentioned. Examples include the growing privatization of institutional corrections; the maturing movement for professional accreditation of prisons and prison systems; oversight of the rapid expansion in the numbers of prisons, prison staff, and prisoners; and handling of the problems created inside prisons by modern drug use patterns and policies. McDonald (in this volume) examines the nettlesome problem of health care provision inside prison and illustrates the complex lattice of management, resource, and political frameworks within which prison managers must operate.

\section{The Political Economy of Prisons}

No one can know what people 100 years from now will find interesting, important, or cautionary about prisons and punishment at the twentieth century's end. From our chronocentric perspective the most striking and distinctive feature of American punishment polices, both historically and comparatively, is the last quarter century's expansion in imprisonment. Older literatures attempted to explain the functions and purposes of imprisonment (Garland 1990, 1991), as have some works by historians (Foucault 1978; Ignatieff 1978; Rothman 1980), but only a small contemporary literature tries to explain the reasons why contemporary prisons policies have developed as they have. Caplow and Simon examine some of that work in this volume. 
The political economy of the American prison has changed enormously over the past twenty-five years. By and large outside partisan politics before 1960, prisons and punishment policies have been political staples since the middle 1960s. Mostly immune from judicial oversight under the "hands-off" doctrine before 1970, nearly every detail of prison management came under intense and often critical scrutiny by federal judges. Nearly entirely within the authority of public officials and employees except for minor contracted services before 1975, prisons are now often managed by private corporations that operate hundreds of institutions and provide comprehensive services, such as medical care systems, to others. Although prison administrators needing to build new facilities were often before 1980 stymied by not-inmy-backyard (NIMBY) movements, communities now compete for new prison construction as local economic development initiatives. Thirty years ago, there were no labor unions for prison guards; today in at least one state, the prison guards union is a major contributor to electoral campaigns and an active lobbyist for particular penal policies.

Private-sector analysts commonly speak of the stakeholders in private businesses-managers, employees, customers, sometimes the general public. In the prisons business, where a quarter century ago the stakeholders were principally public officials and employees, prisoners, and a nebulous sense of the public interest, the stakeholders today include these but also voters, labor unions, private for-profit corporations, communities housing prisons, and the politicians, lobbyists, and political organizations that represent all these interests.

We are too close to our own times to be able to look behind crime rates and punishment policies to understand why so many people are held in American prisons and why some of them are being held for so long. Whatever the true explanations, they are much more complicated than allusions merely to rising crime rates, law-and-order politics, or a vengeful public might suggest. Researchers from many disciplines using many methods study prisons, and many more of them should do so in the future. Adding up the numbers of people admitted into or held in prisons and jails, the people who work in those institutions, the members of both groups' families, and the residents of communities housing penal institutions, tens of millions of people are directly affected by prisons. Any social institution affecting so many people should receive much more attention from scholars than prisons now do. Norval Morris has often said that prisons are a microcosm of society and that if we study them we will learn about ourselves. That 
is another, perhaps the best, reason for increased investment in prison research.

Adams, Kenneth. 1992. "Adjusting to Prison Life." In Crime and fustice: $A R e-$ view of Research, vol. 16, edited by Michael Tonry. Chicago: University of Chicago Press.

Albrecht, Hans-Jörg. 2000. "Post-adjudication Dispositions in Comparative Perspective." In Sentencing and Sanctions in Western Countries, edited by Michael Tonry and Richard Frase. New York: Oxford University Press. (Forthcoming.)

Anderson, Elijah. 1998. "The Social Ecology of Youth Violence." In Youth Violence, edited by Michael Tonry and Mark H. Moore. Vol. 24 of Crime and fustice: A Review of Research, edited by Michael Tonry. Chicago: University of Chicago Press.

Blumstein, Alfred, and Allen J. Beck. In this volume. "Population Growth in U.S. Prisons, 1980-1996."

Blumstein, Alfred, Jacqueline Cohen, and Daniel Nagin, eds. 1978. Deterrence and Incapacitation: Estimating the Effects of Criminal Sanctions on Crime Rates. Washington, D.C.: National Academy Press.

Blumstein, Alfred, Jacqueline Cohen, Jeffrey Roth, and Christy Visher, eds. 1986. Criminal Careers and "Career Criminals." Washington, D.C.: National Academy Press.

Bottoms, Anthony. In this volume. "Interpersonal Violence and Social Order in Prisons."

Braithwaite, John. 1999. "Restorative Justice: Assessing Optimistic and Pessimistic Accounts." In Crime and 7ustice: $A$ Review of Research, vol. 25, edited by Michael Tonry. Chicago: University of Chicago Press. (Forthcoming.)

Bureau of Justice Statistics. 1999. Prisoners and Fail Inmates at Mid-Year 1998. Washington, D.C.: U.S. Department of Justice, Bureau of Justice Statistics.

Caplow, Theodore, and Jonathan Simon. In this volume. "Understanding Prison Policy and Population Trends."

Clemmer, Donald. 1940. The Prison Community. New York: Holt, Rinehart \& Winston.

Cook, Philip J. 1980. "Research in Criminal Deterrence: Laying the Groundwork for the Second Decade." In Crime and fustice: An Annual Review of Research, vol. 2, edited by Norval Morris and Michael Tonry. Chicago: University of Chicago Press.

Elias, Norbert. 1978. The History of Manners: The Civilising Process, vol. 1. Oxford: Basil Blackwell. (Originally published 1939. Basel: Hans Zum Falken.) - 1982. State Formation and Civilization: The Civilising Process, vol. 2. 
Oxford: Basil Blackwell. (Originally published 1939. Basel: Hans Zum Falken.)

Fagan, Jeffrey, and Richard B. Freeman. 1999. "Crime and Work." In Crime and Fustice: $A$ Review of Research, vol. 25, edited by Michael Tonry. Chicago: University of Chicago Press. (Forthcoming.)

Fagan, Jeffrey, and Deanna L. Wilkinson. 1998. "Guns, Youth Violence, and Social Identity in Inner Cities." In Youtb Violence, edited by Michael Tonry and Mark H. Moore. Vol. 24 of Crime and Justice: A Review of Research, edited by Michael Tonry. Chicago: University of Chicago Press.

Fellner, Jamie, and Marc Mauer. 1998. "Nearly 4 Million Americans Denied Vote Because of Felony Convictions." Overcrowded Times 9(5):1, 6-13.

Foucault, Michel. 1978. Discipline and Punish. Translated by Alan Sheridan. New York: Pantheon.

Friedman, Lawrence. 1993. Crime and Punisbment in American History. New York: Basic.

Gaes, Gerald G. 1985. "The Effects of Overcrowding in Prison." In Crime and Fustice: An Annual Review of Research, vol. 6, edited by Michael Tonry and Norval Morris. Chicago: University of Chicago Press.

Gaes, Gerald G., Timothy J. Flanagan, Larry Motiuk, and Lynn Stewart. In this volume. "Adult Correctional Treatment."

Garland, David. 1990. Punisbment and Modern Society: A Study in Social Theory. Oxford: Oxford University Press; Chicago: University of Chicago Press.

- 1991. "Sociological Perspectives on Punishment." In Crime and Fustice: A Review of Research, vol. 14, edited by Michael Tonry. Chicago: University of Chicago Press.

Glaser, Daniel. 1964. The Effectiveness of a Prison and Parole System. Indianapolis: Bobbs-Merrill.

Greenwood, Peter W., Karyn E. Model, C. Peter Rydell, and James Chiesa. 1996. Diverting Cbildren from a Life of Crime: Measuring Costs and Benefits. Santa Monica, Calif.: Rand.

Gurr, Ted Robert. 1989a. "Historical Trends in Violent Crime: England, Western Europe, and the United States." In Violence in America: The History of Crime, vol. 1, edited by T. R. Gurr. Newbury Park, Calif.: Sage.

- ed. 1989b. Violence in America: The History of Crime, vol. 1. Newbury Park, Calif.: Sage.

Hagan, John, and Ronit Dinovitzer. In this volume. "Collateral Consequences of Imprisonment for Children, Communities, and Prisoners."

Hawkins, Gordon. 1976. The Prison-Policy and Practice. Chicago: University of Chicago Press.

Ignatieff, Michael. 1978. A 7ust Measure of Pain: The Penitentiary in the Industrial Revolution, 1750-1850. New York: Pantheon.

Jacobs, James. 1977. Stateville: The Penitentiary in Mass Society. Chicago: University of Chicago Press.

Lane, Roger. 1980. "Urban Police and Crime in Nineteenth-Century America." In Crime and 7ustice: An Annual Review of Research, vol. 2, edited by Norval Morris and Michael Tonry. Chicago: University of Chicago Press. 
1989. "On the Social Meaning of Homicide Trends in America." In Violence in America: The History of Crime, vol. 1, edited by T. R. Gurr. Newbury Park, Calif.: Sage.

_. 1992. "Urban Police and Crime in Nineteenth-Century America." In Modern Policing, edited by Michael Tonry and Norval Morris. Vol. 15 of Crime and 7ustice: $A$ Review of Research, edited by Michael Tonry. Chicago: University of Chicago Press.

Liebling, Alison. In this volume. "Prison Suicide and Prisoner Coping."

Lipton, Douglas, Robert Martinson, and Judith Wilks. 1975. The Effectiveness of Correctional Treatment: A Survey of Correctional Treatment Evaluations. New York: Praeger.

Loeber, Rolf, and David P. Farrington. 1998. Serious and Violent Youthful Offenders: Risk Factors and Successful Interventions. Newbury Park, Calif.: Sage.

Loeber, Rolf, and Magda Stouthamer-Loeber. 1986. "Family Factors as Correlates and Predictors of Juvenile Conduct Problems and Delinquency." In Crime and 7ustice: An Annual Review of Research, vol. 7, edited by Michael Tonry and Norval Morris. Chicago: University of Chicago Press.

Martinson, Robert. 1974. "What Works? Questions and Answers about Prison Reform." Public Interest 35(2):22-54.

Mayhew, Pat, and Jan J. M. van Dijk. 1997. Criminal Victimisation in Eleven Industrialised Countries. The Hague: Dutch Ministry of Justice.

McDonald, Douglas C. In this volume. "Medical Care in Prisons."

Miller, Ted R., Mark A. Cohen, and Brian Wiersema. 1996. Victim Costs and Consequences: A New Look. Washington, D.C.: U.S. Department of Justice, National Institute of Justice.

Nagin, Daniel S. 1998a. "Deterrence and Incapacitation." In The Handbook of Crime and Punishment, edited by Michael Tonry. New York: Oxford University Press.

- 1998b. "Criminal Deterrence Research at the Outset of the TwentyFirst Century." In Crime and 7ustice: $A$ Review of Research, vol. 23, edited by Michael Tonry. Chicago: University of Chicago Press.

Ohlin, Lloyd E. 1951. Selection for Parole: A Manual of Parole Prediction. New York: Russell Sage.

Petersilia, Joan. 1997a. "Justice for All? Offenders with Mental Retardation and the California Corrections System." Prison Fournal 77:355-380.

- 1997b. "Unequal Justice? Offenders with Mental Retardation in Prison." Corrections Management Quarterly 1(4):35-45.

—. In this volume. "Parole and Prisoner Reentry in the United States."

Pranis, Kay. 1996. "Restorative Justice Catching on in Minnesota Corrections." Overcrowded Times 7(2):1, 9-11.

Reiss, Albert J., and Jeffrey Roth, eds. 1993. Understanding and Controlling Violence. Washington, D.C.: National Academy Press.

Riveland, Chase. In this volume. "Prison Management Trends, 19752025."

Rothman, David J. 1980. Conscience and Convenience: The Asylum and Its Alternatives in Progressive America. Boston: Little, Brown. 
Sparks, R., A. E. Bottoms, and W. Hay. 1996. Prisons and the Problem of Order. Oxford: Clarendon.

Spelman, William. 2000. "Prisons and Crime: What Recent Studies Do (and Don't) Tell Us." In Crime and Justice: $A$ Review of Research, vol. 27, edited by Michael Tonry. Chicago: University of Chicago Press. (Forthcoming.)

Sykes, Gresham. 1958. The Society of Captives. Princeton, N.J.: Princeton University Press.

Sykes, Gresham, and Sheldon Messinger. 1960. "The Inmate Social System." In Theoretical Studies in the Social Organization of the Prison, edited by Richard Cloward. New York: Social Science Research Council.

Tyler, R. T. 1990. Why People Obey the Law. New Haven, Conn.: Yale University Press.

von Hirsch, Andrew, Anthony Bottoms, Elizabeth Burney, and P.-O. Wikström. 1998. Criminal Deterrence and Sentence Severity: An Analysis of Recent Research. Oxford: Hart Press.

Walker, Samuel. 1998. Popular fustice: A History of American Criminal fustice, rev. ed. New York: Oxford University Press.

Welsh, Brandon C., and David P. Farrington. 2000. "Monetary Costs and Benefits of Crime Prevention Programs." In Crime and Fustice: $A$ Review of Research, vol. 27, edited by Michael Tonry. (Forthcoming.)

Wilson, James Q., and Richard Hernstein. 1985. Crime and Human Nature. New York: Simon \& Schuster.

Zedner, Lucia. 1995. "Wayward Sisters: The Prison for Women." In The Oxford History of the Prison: The Practice of Punishment in Western Society, edited by Norval Morris and David J. Rothman.

Zimring, Franklin E., and Gordon Hawkins. 1991. The Scale of Imprisonment. Chicago: University of Chicago Press. 